NBER WORKING PAPER SERIES

\title{
EVALUATING THE ROLE OF BROWN VS. BOARD OF EDUCATION IN SCHOOL EQUALIZATION, DESEGREGATION, AND THE INCOME OF AFRICAN AMERICANS
}

\author{
Orley Ashenfelter \\ William J. Collins \\ Albert Yoon \\ Working Paper 11394 \\ http://www.nber.org/papers/w11394 \\ NATIONAL BUREAU OF ECONOMIC RESEARCH \\ 1050 Massachusetts Avenue \\ Cambridge, MA 02138 \\ June 2005
}

Ashenfelter is the Joseph Douglas Green 1895 Professor of Economics at Princeton University. Collins is an Associate Professor of Economics at Vanderbilt University. Yoon is an Associate Professor of Law at Northwestern University. The authors appreciate suggestions from Martha Bailey, Liz Cascio, Robert Margo, Sean Reardon, Sarah Reber, Stewart Schwab, participants in Princeton University's Brown v. Board of Education Conference (October 2004), and participants in a session of the Social Science History Association Meetings (November 2004). Jonathan Thornhill provided timely research assistance. Part of this research was supported by NSF Grant 0095943 . The views expressed herein are those of the author(s) and do not necessarily reflect the views of the National Bureau of Economic Research.

(O2005 by Orley Ashenfelter, William J. Collins, and Albert Yoon. All rights reserved. Short sections of text, not to exceed two paragraphs, may be quoted without explicit permission provided that full credit, including (C) notice, is given to the source. 
Evaluating the Role of Brown vs. Board of Education in School Equalization, Desegregation, and the Income of African Americans

Orley Ashenfelter, William J. Collins, and Albert Yoon

NBER Working Paper No. 11394

June 2005

JEL No. J7, I28, N32

\begin{abstract}
$\underline{\text { ABSTRACT }}$
In this paper we study the long-term labor market implications of school resource equalization before Brown and school desegregation after Brown. For cohorts born in the South in the 1920s and 1930s, we find that racial disparities in measurable school characteristics had a substantial influence on black males' earnings and educational attainment measured in 1970, albeit one that was smaller in the later cohorts. When we examine the income of male workers in 1990, we find that southern-born blacks who finished their schooling just before effective desegregation occurred in the South fared poorly compared to southern-born blacks who followed behind them in school by just a few years.

Orley Ashenfelter

Industrial Relations Section

Firestone Library

Princeton University

Princeton, NJ 08544

and NBER

c6789@princeton.edu

William J. Collins

Department of Economics

Box 351819-B

Vanderbilt University

Nashville, TN 37235

and NBER

william.collins@vanderbilt.edu
\end{abstract}

Albert Yoon

Northwestern University School of Law

357 East Chicacgo Avenue

Levy Mayer 272

Chicago, IL 60611

albertyoon@northwestern.edu 


\section{Introduction}

In this paper we discuss a framework for evaluating the effect of the Supreme Court's landmark 1954 decision in Brown v. Board of Education of Topeka on the welfare of African Americans in the labor market. In principle, this extraordinary event created a dramatic "program" with which to evaluate the role of school resources and their organization on labor market outcomes. The public profile of the Brown decision, however, tends to overshadow two facts that are now well established. First, racial disparities in school resources in the South began narrowing 20 years before the Brown decision (Margo 1990, Card and Krueger 1992, Donohue, Heckman, and Todd 2002). Second, school desegregation did not begin on a large scale in the Deep South until ten years after the Brown decision (U.S. Commission on Civil Rights 1967, 1977; Welch and Light 1987; Donohue and Heckman 1991; Boozer, Krueger, and Wolkon 1992; Reber 2003; Clotfelter 2004). In short, the Brown decision did not create a discrete program at all.

Although the Brown decision is often viewed as a watershed in the history of discrimination and segregation in the United States, we think it should instead be viewed as a highly visible marker of public policy's mid-century reversal on matters of race. In effect, therefore, studying the impact of the Brown decision on labor market outcomes must be the study of a long-term process that slowly, but surely, restored some of the promise offered by the Abolitionists at the time of the Civil War (McPherson 1964).

The equalization of school resources occurred gradually over time and unevenly across states whereas the effective desegregation of public schools, particularly in the Deep South, occurred much more suddenly, albeit a full decade after the Brown decision. In this paper, we use the cross-state variation in school resources and the suddenness of desegregation to shed light on the long-term labor market implications of school resource equalization before Brown and school desegregation after Brown.

For cohorts born in the South in the 1920s and 1930s, we find that racial disparities in measurable school characteristics had a substantial influence on black males' earnings, albeit one that was smaller in later cohorts. In a rough counterfactual, we estimate that southern-born black men's annual income in 1970 would have been from 5 to 9 percent (1920s birth cohort) or 2 to 5 percent (1930s birth cohort) 
higher if they had gone to schools with the same student/teacher ratio or the same length of school year as whites born at the same time and in the same state. We also find that the link between school quality and subsequent income was made primarily through increased educational attainment. Because easily measurable (and litigable) disparities in school resources had greatly narrowed in most states by 1950 , there may have been few direct economic gains associated with a continued pursuit of the "equal" part of the "separate but equal" doctrine.

By that time, the NAACP's lawyers were aggressively attacking the policy of segregation itself, including testimony on the social and educational impact of segregation per se on black students (Kluger 1975). When we examine the labor market outcomes of male workers in 1990, we find that southernborn blacks who finished their schooling just before effective desegregation occurred in the South fared poorly compared to southern-born blacks who followed behind them in school by just a few years, relative to northern-born blacks in same age cohorts. This finding is robust to adding controls for stateof-residence effects, and it is not merely reflective of an upward trend in southern-born men's income relative to that of northern-born men. Again, a portion of the correlation between the change in the schooling environment and subsequent income reflects improvements in southern-born blacks' level of educational attainment. While these results are consistent with a growing econometric literature that suggests that desegregation had a positive influence on blacks' educational and labor market outcomes, we view them as suggestive patterns that call for more extensive research.

\section{School Resources and the Limits of Equalization}

In the pre-Brown period, southern school districts typically ran dual systems with completely separate schools for whites and blacks. In fact, on the eve of the Brown decision, the Southern Education Reporting Service (SERS) found that essentially no black children attended school with white children in public schools in the Deep South, and that very few black children in Border States did. ${ }^{1}$ Clearly, the

\footnotetext{
${ }^{1}$ See Southern Education Reporting Service (1965). In this case, "Deep South" refers to Alabama, Arkansas, Florida, Georgia, Louisiana, Mississippi, North Carolina, South Carolina, Tennessee, Texas, and Virginia. "Border
} 
"separate" part of "separate but equal" was strictly enforced in the South, but what about the "equal" part? And what were the long-term labor market consequences of disparities in school characteristics?

\section{The Changing Gap in School Resources}

After the Civil War, blacks and the federal government exercised a significant measure of political influence in the South, and consequently, new state constitutions included provisions for the public education of all children and civil rights for black citizens (Anderson 1988). This influence did not last long. In the post-Reconstruction era (after 1877), southern governments succeeded in rolling back blacks' civil liberties, including their right to vote. ${ }^{2}$ Eventually, white-dominated county school boards funneled disproportionate shares of state funds, which had been allocated on the basis of the number of school-aged children, to white schools (Bond 1934, Margo 1990). Through the first third of the twentieth century, wide inter-racial disparities in basic measures of school inputs were the norm in the South.

Table 1 reports estimated racial gaps in days of school per term (panel A) and students per teacher (panel B). The figures in the table were originally reported by Margo (1990), Card and Krueger (1992), and Donohue, Heckman, and Todd (2002). The underlying data are derived primarily from reports of state education officials or the U.S. Office of Education's Biennial Survey of Education. Although the base figures are subject to some degree of error and the authors have taken somewhat different approaches to collecting and reporting the data, the basic picture is clear. According to Margo's data, racial quality gaps tended to widen between 1890 and 1910 as the number of school days (and expenditures) for black schools failed to keep pace with those for white schools. ${ }^{3}$ From 1910 to 1930 there were large differences in the number of days of instruction offered at black schools compared to white schools (around 30 school days according to Card and Krueger's estimate for the whole South), and

states" refers to Delaware, Kentucky, Maryland, Missouri, Oklahoma, Washington DC, and West Virginia. Later in the paper, we include Kansas with the Border States.

${ }^{2}$ Much of the undermining of blacks' civil liberties was facilitated by the Supreme Court itself. See Katz (2003), writing that "[r]ead together, decisions such as United States v. Reese, United States v. Cruikshank, United States v. Harris, and the Civil Rights Cases undeniably restricted congressional power to enforce the newly ratified Reconstruction-era Amendments."

${ }^{3}$ Our table lists only Margo's figures for Alabama, but the widening gap from 1890 to 1910 pertains to other southern states as well. 
in the number of pupils per teacher (from 10 to 20 students depending on the year, state, and weighting method). ${ }^{4}$ According to all three sources of figures cited in Table 1, the gaps narrowed after the mid1930s. Donohue, Heckman, and Todd (2002) argue that NAACP litigation, discussed below, played a key role in promoting those post-1935 gains. They also cite the importance of private philanthropy in improving black education, primarily before the mid-1930s.

Comprehensive information on "teacher quality" is scarce, especially early in the period under study. From 1940 to 1960, however, we can observe the years of educational attainment for black and white teachers in the census. ${ }^{5}$ In this period, southern black teachers taught only black students, and relatively few white teachers instructed black students. Therefore, a narrowing racial gap in southern teachers" educational attainment would suggest convergence in "teacher quality" for black and white students. In 1940, southern black teachers had an average of 13.9 years of education (median 14 years) compared to white teachers average of 15.1 years (median 16 years). By 1960, southern black teachers had an average of 15.8 years of education (median 16 years) compared to whites' average of 15.7 (median 16 years). ${ }^{6}$ In this dimension, the racial gap had disappeared before large-scale desegregation in the South, but more finely-tuned cross-race comparisons of teacher quality suggest that a gap may have remained as late at 1965. The Coleman Report, for example, found that on average teachers at white schools scored somewhat higher on a short, voluntary "verbal facility" test than teachers at black schools — teachers at black secondary schools scored at about 85 to 90 percent of the white average (Coleman 1966, p. 134). The extent to which such differences mattered to teachers' and students' performance is unknown.

Some important aspects of racial disparities in the provision of public education are not

\footnotetext{
${ }^{4}$ In 1935-36 there is a high correlation coefficient (0.89) between the black/white ratio of school term length and the black/white ratio of average days of school attendance in southern and border states (Wilkerson 1939, reprinted 1970, p. 9).

${ }^{5}$ We use the 1940 and 1960 IPUMS samples and select those listed with the "teacher" occupation code (093) and "education" industry code (888).

${ }^{6}$ It is unknown whether white and black teachers with similar levels of education were actually equally well-trained. Most southern black teachers in this period would have been the products of the South's discriminatory educational system, implying less "quality" embedded in each year of their education. On the other hand, because so many nonteaching employment opportunities were closed to well-educated blacks, there may have been positive selection on
} 
represented in Table 1. For example, up to at least 1930, many southern blacks, especially in rural areas, did not reside in reasonable proximity to existing black high schools. According to Caliver (1933, p. 31), about 30 percent of southern counties, all with substantial black populations, did not offer standard high school educations for blacks. ${ }^{7}$ In the South in 1930, it appears that there were approximately 60 "potential" white high school students (based on age) per employed white high school teacher, compared to 211 "potential" black high school students (Caliver 1933, p. 20). Wilkinson (1939) also describes the ways in which existing blacks' schools were physically inferior to those attended by whites, both structurally and in terms of instructional materials.

Although there may be considerable scope for expanding and refining our quantitative characterization of the racial gaps in school quality, the levels and trends in Table 1 may be reasonable proxies for other, less well-documented, dimensions of school quality. For example, the black/white ratio of length of school term (from Card and Krueger 1992, for the 1920-29 birth cohort) is highly correlated with the black/white ratio of the value of school properties and equipment in 1935-36. For the 10 states with overlapping data, the correlation coefficient is 0.7 ( $\mathrm{p}$-value $=0.03$ ) (from Wilkinson 1939). Moreover, across southern states, average term lengths for southern black students in the 1920-29 birth cohort (and the 1930-39 birth cohort) are highly correlated with average years of education for black teachers in the 1940 IPUMS sample (correlation coefficient is 0.78 , p-value $=0.0004$ ).

\section{The NAACP, Equalization, and Segregation: A Brief Legal History}

The legal landscape at the turn of the twentieth-century was not conducive to the advancement of African Americans' educational interests. In Plessy v. Ferguson (1896) the Supreme Court affirmed the right of states to enforce racial segregation "for the promotion of the public good." ${ }^{8}$ In Cumming $v$.

ability into the black teaching ranks (relative to whites). We expect that the changes in the levels of education within race categories do reflect true convergence in teacher quality.

${ }^{7}$ About 16 percent of the counties had no high schools at all for blacks, and an additional 14 percent did not have four-year high schools for blacks. South Carolina is not included in Caliver's sample.

${ }^{8}$ Although Plessy dealt specifically with the right of railways to segregate passengers on the basis of race into "equal but separate" accommodations, the principles of the decision extended to educational policy. In fact, the Court's opinion explicitly cites school segregation as a reasonable exercise of a state's police power: "The most common instance of this [exercise of police power] is connected with the establishment of separate schools for white 
Richmond County Board of Education (1899), the Supreme unanimously rejected the argument that inequality in school resources violated the Fourteenth Amendment's equal protection clause. In subsequent Supreme Court decisions it became evident that, in theory, educational institutions could be required to provide reasonably equal accommodations when maintaining a system of racial separation (Tushnet 1987, pp. 21-25). ${ }^{9}$ But the barriers to promoting blacks' educational opportunities through the judicial system remained formidable, and with widespread disenfranchisement of southern black voters, the legislative channel was even less promising.

In preparing a grant application for the Garland Fund in 1929, the NAACP formed a preliminary plan to launch a series of lawsuits that would challenge segregation and discrimination in the South. ${ }^{10}$ One objective was to equalize school expenditures, perhaps thereby making the dual school system unsustainably expensive (thus, an indirect attack on segregation). Nathan Margold, hired by the NAACP in 1930, was critical of this strategy and devised a more carefully thought out plan of attack. Margold was keenly aware of the organization's limited resources, its legal options in the federal court system, and the Supreme Court's likely response to each of those options. In this context, Margold argued that lawsuits seeking to equalize expenditures as written in state law would be numerous, complex, costly, and potentially ineffective even if won, since most states allowed county-level discretion in spending across schools and since new suits would have to be filed every year. Margold wrote, “. . . the very multiplicity of suits which would have to be brought is itself appalling. . . It would be a great mistake to fritter away our limited funds on sporadic attempts to force the making of equal divisions of school funds in the few instances where such attempts might be expected to succeed" (quoted in Kluger 1975, p. 134).

Instead of seeking equalized spending within school districts, Margold believed that state officials, empowered to invest equally in black and white schools, violated the Constitution when they presided over schools with unequal funding. His legal strategy was to seek judicial declarations that the

and colored children, which has been held to be a valid exercise of the legislative power even by courts of States where the political rights of the colored race have been longest and most earnestly enforced."

${ }^{9}$ See in particular McCabe v. Atchison, Topeka \& Santa Fe Railroad (1914) on the provision of equal accommodations in railcars.

${ }^{10}$ This section draws heavily from Tushnet (1987, chapters 1 and 2). 
funding of particular schools was unconstitutional on the grounds that "segregation coupled with discrimination resulting from administrative action permitted but not required by state statute, is just as much a denial of equal protection of the laws as is segregation coupled with discrimination required by express statutory enactment" (quoted in Tushnet 1987, p. 28). In so doing, the NAACP could litigate the funding inequities of an individual school within a state to invalidate the funding of that state's entire educational system. If successful, these declarations would force southern school officials to choose between two alternatives: raising expenditures for black schools or providing one set of schools for all children.

The NAACP, while recognizing that the Margold Plan's strategy was bold and imbued with remarkable legal insight, opted against fully implementing it. In short, in the context of the South in the 1930s, the NAACP feared a backlash from a direct attack on segregation in elementary and secondary schools. Moreover, important constituencies within the organization and the black community were ambivalent about segregated schooling. The Margold Plan, however, did clarify the legal principles and opportunities, and became "the Bible of the NAACP legal drive." (Kluger 1975, p. 136). For two decades, the NAACP pursued a series of cases involving discrimination in teachers' pay and admission to professional schools. These cases laid some of the legal and political groundwork for Brown, catered to (and built up) particular constituencies within the NAACP, and spurred southern school administrators and politicians to improve the relative quality of black schools in the hope of heading off a direct challenge to segregation per se.

By the time southern school boards took the "equal" part of "separate but equal" seriously, however, the NAACP was moving beyond litigating "equal." Notwithstanding the fact that some school districts provided greater parity between black and white schools, the NAACP was ready to tackle "separate" itself. By the late 1940s, political currents and changes in the Court had raised the likelihood of success in a direct challenge to segregation in primary and secondary schools, success that finally arrived in the Brown ruling (Klarman 1994). 


\section{Previous Work on the Importance of Pre-Brown Racial Disparities in School Resources}

In Brown, the NAACP argued that segregated schooling "inheres in the retardation of intellectual development and distortion of personality" of black students (Appellant's Brief, p. 5). During oral argument, Thurgood Marshall cited sociological studies that claimed that segregated schools destroyed black children's self-respect and stamped them "with a badge of inferiority" (Oral Argument, Briggs v. Elliott, p. 3). Since Brown, economists have attempted to measure the impact of the separate-but-equal regime several times, with an emphasis on educational outcomes such as school attendance and literacy rather than post-schooling labor market outcomes. For example, Margo (1986) studied county-level data for Alabama from 1920 to 1940 and found that equalizing school-term length would have narrowed the racial gap in literacy rates (for 7 to 20 year olds) by about 25 percent. ${ }^{11}$ A subsequent paper by Margo (1987) on school attendance in 1900 also found that equalizing school characteristics would have narrowed the racial gap, but that family characteristics (such as parents' literacy and household head's occupational status) were quantitatively more important, a point that is echoed in our analysis of income gaps below.

Orazem (1987) offered the literature's only estimate (to our knowledge) of an effect on standardized test scores in the pre-Brown period. Using county-level race-specific data from Maryland for the 1920s and 1930s, he found that the length of the school term influenced test performance and that differences in school characteristics could account for about 40 percent of the large racial gap in average scores. Each of the studies mentioned above made the best use of highly imperfect data, and so considerable care must be taken in interpreting the results. Nonetheless, the fundamental point that school resources mattered to southern black children's educational attainment, albeit not as much as their family's economic resources, is fairly clear.

Due to the intergenerational nature of human capital transmission and investment, the cumulative effects of discrimination in education may be much larger than the point-in-time estimates suggest.

\footnotetext{
${ }^{11}$ Margo's (1986) results vary depending on whether fixed or random effects estimates are used and whether black or white coefficients are used in the decomposition. We have chosen an average of all the estimates which happens to be close to the estimates based on black coefficients from fixed effects regressions.
} 
However, from a strategic policy point of view (e.g., that of Civil Rights activists), the past would have to be taken as given, and so the point-in-time estimates are highly relevant to discussions of the hypothetical impact of a policy that would equalize rough measures of school quality.

The labor market implications of the pre-Brown racial gap in school resources are not precisely known. The work above suggests that increasing school resources for blacks would have increased average black educational attainment. Moreover, Collins and Margo (2003) found positive returns to literacy for blacks who worked in the South prior to 1940; others have found that literacy increased the likelihood of migration from the South to higher wage regions (Margo 1990, Vigdor 2002); and Smith and Welch (1989) documented positive returns to education for blacks from 1940 onwards.

Card and Krueger (1992) went much further towards establishing a direct link between southern school quality and subsequent earnings. First, they argued that changes in school quality explain a large part of the racial convergence in returns to education for cohorts born between 1910 and 1940, and that this inter-cohort convergence accounts for a nontrivial portion of the total amount of racial convergence in returns to education observed for workers from 1960 to 1980 . Then, in reduced-form estimates that do not attempt to trace school quality effects through changing returns to education, Card and Krueger found a significant correlation between the racial gap in student/teacher ratios and the racial gap in wages across state-by-decade-of-birth cohorts. They concluded that 15 to 20 percent of the racial wage convergence among southern-born men that occurred between 1960 and 1980 was attributable to changes in school quality (1992, p. 193). Heckman, Layne-Ferrar, and Todd (1996) and Card and Krueger (1996) revisit this investigation and debate the interpretation of the findings and the appropriateness of the econometric methodology. ${ }^{12}$

\section{Resource Gaps and Implied Wage Losses}

Card and Krueger (1992) focus on school quality and the change in racial wage gap between 1960

\footnotetext{
${ }^{12}$ A central criticism by Heckman, Layne-Ferrar, and Todd (1996) is that the specifications in Card and Krueger (1992) do not allow for selection in migration. See Card and Krueger (1996) for additional discussion of their 1992
} 
and 1980. Here, we pose a related but distinct question regarding school resources. If black workers who were born in the 1920s and 1930s had been allocated the same (roughly measured) school resources as white students, how much higher might their incomes have been in $1970 ?^{13}$ We attempt to answer the question in two parts: first, by estimating the returns to school quality; second, by adjusting black levels of school quality to match those of whites in the same cohort. This is a partial equilibrium estimate that assumes that equalization was possible without a reduction in the resources sent to white schools, but it may still provide a reasonable guide to the orders of magnitude involved.

We start by estimating the following regression for southern-born black men in the IPUMS 1970 state sample:

$$
\mathrm{Y}_{\mathrm{icrs}}=\alpha+\theta_{\mathrm{c}}+\gamma_{\mathrm{r}}+\delta_{\mathrm{b}}+\lambda_{\mathrm{rb}}+\beta_{1} \mathrm{PE}_{\mathrm{cs}}+\beta_{2} \mathrm{Q}_{\mathrm{cs}}+\mathrm{e}_{\mathrm{i}}
$$

where $\mathrm{Y}$ is log income in 1970; $\theta$ is a birth cohort dummy (1920s or 1930s) ${ }^{14} \gamma$ is a region-of-residence vector of dummies (nine census regions); $\delta$ is a southern sub-region of birth vector of dummies (Border State, South Atlantic, East South Central, or West South Central), and $\lambda$ is a vector of interactions between sub-regions of birth and residence. Q is a measure of school quality for birth-state s and cohort $\mathrm{c}$ (student/teacher ratio or length of school term) taken from Card and Krueger (1992, appendix 3). This is essentially what Card and Krueger (1996) refer to as a "Class IV" approach to estimating the effects of school quality on earnings. The main advantage of this approach is that it allows school quality to affect earnings through several channels, including both increased educational attainment and higher returns from any given level of attainment.

We are concerned that, even allowing for fixed effects by sub-region of birth, sub-region of residence, and the interaction of birth and residence sub-regions, measured school quality may be

work in light of Heckman et al.'s criticism. With this exchange in mind, we include interactions of birth sub-region and residence sub-region, in addition to birth and residence sub-region fixed effects in some of our regressions. ${ }^{13}$ Thus, whereas Card and Kruger (1992) focus on the change in the racial gap in wages from 1960 to 1980, we focus on the level of black income in 1970. Note that our approach is closer in spirit to the reduced-form estimates that Card and Krueger pursue at the end of their paper (as opposed to their efforts to trace the effect of quality improvements through the estimated returns to schooling). We take this approach because there is evidence that changes in school quality influenced both the level of educational attainment and the returns to any given level of attainment (Card and Krueger 1996).

${ }^{14}$ Adding a quartic in age has little effect on the coefficients of interest. 
correlated with unobserved factors that also influenced labor market outcomes later in life. Specifically, parents' educational attainment is typically among the most important explanatory variables of children's educational attainment, and because parents often live in the state they grew up in, it is likely to be correlated with their children's school quality (to the extent that state differences in school quality are persistent). Therefore, in some specifications we have added a birth-state-by-cohort-specific control variable for adult black educational attainment during the 1920s and 1930s, denoted $\mathrm{PE}_{\mathrm{cs}}$ in the equation above. $^{15}$

Columns 1 to 5 of Table $2 \mathrm{~A}$ report results for specifications in which the student/teacher ratio is used as the measure of school quality. Such ratios are frequently used as a gauge of school quality, but the underlying historical data come with several caveats, including occasional misreporting and differences between enrollment and attendance-based figures (see Donohue, Heckman, and Todd 2002). The coefficient estimates are negative in each case, but the magnitude and statistical significance depend somewhat on the specification. ${ }^{16}$ Column 5's results suggest that a decline of 10 students per teacher (approximately the size of the racial gap in 1935/38, reported in Table 1) was associated with an eight percent rise in 1970 income. Quantile regressions of the specification in column 5 (not shown) at the $25^{\text {th }}$, $50^{\text {th }}$, and $75^{\text {th }}$ percentiles suggest slightly stronger effects of school quality at the lower end of the income distribution, but in general, the coefficients are comparable in magnitude to the OLS result.

Columns 6 to 10 use the length of the school year to measure school quality. ${ }^{17}$ The coefficients are fairly stable and statistically significant across specifications, and they all indicate that having a longer school term as a child was associated with higher earnings in 1970. Ten extra days of schooling per term were associated with a 2.4 to 3.8 percent increase in earnings. Again, quantile regressions of the

\footnotetext{
${ }^{15}$ We estimated "parents' education" using the 1940 IPUMS sample. To assign values for the 1920-29 birth cohort, we observed years of education for people of age 35-55 in 1940 in each southern state (who would have been 20-40 in 1925). For the 1930-39 birth cohort, we observed education for people of age 25-45 in 1940 (who would have been 20-40 in 1935). The idea to focus on the age range that was most likely to be having children during each decade.

${ }^{16}$ In columns 4 and 5, if we replace parents' education with measures of state per capita income in 1929 (for first cohort) and 1940 (for second cohort), we get slightly larger results for the school quality effects. We prefer the parents' education variable because it is race specific, whereas race-specific income measures are not available prior to 1940 .
} 
specification in column 10 (not shown) suggest slightly stronger effects of school quality at the lower end of the income distribution, but in general, the coefficients are similar to the OLS result.

Given these estimates of the influence of school quality on blacks' earnings, a counterfactual level of average earnings for southern-born black men can be estimated by re-setting each individual's schooling input measure to equal that of white students in the same state-cohort grouping. Ceteris paribus, how much higher might blacks' earnings have been if school inputs within states had been equal prior to Brown? Based on the student/teacher coefficient in column 5, average earnings would have been $0.085 \log$ points higher for the 1920-29 birth cohort, and 0.049 log points higher for the 1930-39 birth cohort. Based on the length of term coefficient in column 10, average earnings would have been 0.055 $\log$ points higher for the 1920-29 birth cohort, and 0.019 log points higher for the 1930-39 birth cohort.

The unadjusted racial income gap for southern-born men in these cohorts in 1970 is $0.59 \log$ points for those born in the 1920s and 0.49 for those born in the 1930s. Therefore, about 9 to 14 percent of the gap for the 1920 s cohort may be accounted for differences in school quality $(0.055 / 0.59$ or $0.085 / 0.59)$, and about 4 to 10 percent of the gap for the 1930s cohort may be accounted for by differences in school quality $(0.019 / 0.49$ or $0.049 / 0.49)$.

These are substantial increments to earnings, but it is worth noting that the estimated impact of the parental education gap is much larger than the estimated impact of the school quality gap. Based on column 5, resetting the variable for black adult educational attainment in the 1920s and 1930s to equal that of whites (in same state), would have added $0.14 \log$ points to the average 1970 earnings of black children who were born in the South in the 1920s and 1930s. ${ }^{18}$ This accounts for about one-quarter of the observed racial wage gap between southern-born white and black men in 1970 (who were born in the 1920s and 1930s). Thus, the intergenerational transfer of racial education gaps was significant, and the cumulative impact of racial discrimination in southern education, which surely accounts for part of the parental education gap, was far-reaching.

\footnotetext{
${ }^{17}$ The student/teacher ratio and term length are highly correlated (correlation coefficient is -0.91), so we do not enter them simultaneously in the regressions.

${ }^{18}$ The estimated impact is very similar for the 1920s and 1930s birth cohorts.
} 
Table 2B reports results from similar specifications, but uses years of education as the dependent variable. Measures of school quality are highly correlated with the men's educational attainment. In fact, nearly all of the effect of school quality on income documented in table 2A works through the educational attainment channel - controlling for educational attainment in Table 2A's specifications (not shown) tends to reduce sharply the magnitude and significance of the coefficients on the school quality variables. For the 1920s birth cohort, according to column 5 of Table 2B, black students would have attained, on average, an extra year of education if they had attended schools that had the same student/teacher ratio as the schools whites attended. For the 1930s birth cohort, the analogous figure is 0.63 years of education. Column 10's estimates imply a smaller educational impact: 0.43 years for the 1920 s birth cohort, and 0.15 years for the 1930s birth cohort. Column 10's results reiterate the importance of intergenerational links, as the coefficients suggest that southern black students of both cohorts would have attained about 1.75 more years of schooling if their parents had had the same educational profile as southern whites; column 5's estimates imply a somewhat smaller impact (1.2 years), but the general point regarding the importance of intergenerational links remains.

As discussed below, the 1940-49 birth cohort was the last to pass through de jure segregated schools in the South. By that time, the limits of equalization may have been reached in the sense that easily observed (and therefore easily litigated) differences in school inputs were small by historical standards and converging rapidly. Mississippi was clearly lagging in this respect. But in general, further efforts to equalize such resources within the segregated regime would have entailed relatively small economic payoffs for the children whose education was at stake. The NAACP's legal initiative had already moved on to a more ambitious target: the system of segregated education itself.

\section{The Impact of School Desegregation on Income}

In 1956, nearly every southern member of Congress signed the "Southern Manifesto" which 
denounced the Brown ruling and pledged to resist desegregation by all legal means. ${ }^{19}$ It is difficult to overstate the initial level of southern white opposition to the idea of racially integrated schools. In 1956, only 14 percent of southern whites thought that black and white students should attend the same school, and that sample includes respondents from the Border States and Washington, DC (Greeley and Sheatsley 1971). ${ }^{20}$ Southern states and local governments exercised a variety of legal tactics to forestall any meaningful school integration, as described by Blaustein and Ferguson (1957, pp. 240-271), and extralegal threats made potential litigants hesitant to pursue the matter. ${ }^{21}$ The minimal amount of integration accomplished in Little Rock, Arkansas in 1957 certainly did not speed the way for widespread desegregation in the Deep South. In perhaps the most egregious evasion of desegregation, Prince Edward County of Virginia closed its public school system from 1959 to 1964 (Murrell 1998). A full five years after Little Rock, less than one percent of southern black students attended school with whites (Southern Education Reporting Service 1965).

Ten years after Brown, however, school desegregation in the South proceeded rapidly as a combined result of the Civil Rights Act of 1964, the Elementary and Secondary Education Act of 1965, and a series of federal court orders. The Civil Rights Act included provisions that could cut funding to discriminatory public institutions (Title VI) and authorized the attorney general to sue segregated school districts (Title IV) (Orfield 1969). Later, the Supreme Court's decision in Green v. County School Board of New Kent County (1968) required the elimination of identifiably black and white schools within school districts, thereby undercutting "freedom-of-choice" plans that had left high levels of racial segregation and requiring busing (if necessary) to achieve racially mixed schools.

The National Survey of Black Americans, first taken in 1979-80, asked respondents to describe the racial composition of the high school they had attended. Separate questions were posed for

\footnotetext{
${ }^{19}$ In part, the document reads, "This unwarranted exercise of power by the Court, contrary to the Constitution, is creating chaos and confusion in the States principally affected. It is destroying the amicable relations between the white and Negro races that have been created through 90 years of patient effort by the good people of both races. It has planted hatred and suspicion where there has been heretofore friendship and understanding."

${ }^{20}$ This figure increased to about 32 percent in 1963 and 44 percent in 1970. See Smith (1981) for an analysis of the trends by region, educational attainment, and age cohort.

${ }^{21}$ See, for examples, Lassister and Lewis (1998) on "Massive Resistance" to school desegregation in Virginia.
} 
elementary and junior high school experiences, but we focus on the high school experience. ${ }^{22}$ In Figure 1 , the proportion of respondents who attended all black high schools is plotted on the vertical axis. The year of birth is plotted on the horizontal axis of the top graph, and year of birth plus 16 years is plotted on the lower graph. Separate plots are shown for blacks who reported that they "grew up mostly" in the South and those who reported growing up mostly outside the South. Those who grew up in Border States are, for now, excluded for purposes of exposition. Implicitly, we assume that respondents went to high school in the place where they reported growing up, but of course, there is some room for error. In any case, the portrait of change is very clear. Up to around the 1948 birth cohort, it was rare for southern blacks to have attended anything other than an all black high school. In contrast, by the 1953 birth cohort, the vast majority of southern blacks did not attend an all black high school. Over the same period, a relatively consistent and low proportion of non-southern respondents reported attending all black high schools. ${ }^{23}$

The rapid change in black southerners' attendance of integrated schools provides an opportunity to take a rough measure of the influence of school integration on southern black students' subsequent labor market outcomes. Our empirical strategy, described in more detail below, is based on a comparison of the income of those who finished their formal schooling just before desegregation took hold in the South and those who came through high school only a few years later, using northern-born blacks to net out age effects. Given that there were efforts to increase the level of racial integration in northern schools around the same time, our measure of the effect of southern desegregation on southern-born blacks is net of any influence of northern desegregation on northern-born blacks. Therefore, if desegregation efforts had a positive influence on black students in all regions, then our estimates may be biased downward.

\section{Previous Work on Desegregation and Labor Market Outcomes}

\footnotetext{
${ }^{22}$ Boozer, Krueger, and Wolkon (1992) plot figures for students in all grades rather than just high school, and they arrange the figure by academic year rather than birth cohort. Nonetheless, the graphs are very similar.

${ }^{23}$ The reported figure for non-southerners (and non-border states) may seem high. A few possible explanations are: 1) some urban blacks may have attended nearly all black schools and simply reported them as "all black"; 2) there is some disconnection between where respondents reported growing up and where they went to high school; 3) some non-southern blacks did attend segregated schools though it was rare by the mid 1950s (see Clotfelter 2004, pp. 1819). We do not have data to help discern among the possibilities.
} 
The 50-year anniversary of the Brown decision elicited an outpouring of journalistic reflection on the decision's implications. Much of it was highly ambivalent, citing the poor performance of racially imbalanced inner-city public schools currently attended by many black students. The malaise that characterizes popular views of desegregation is generally not grounded in careful analyses of the effects of school desegregation. In fact, the existing academic literature contains comparatively few econometric efforts to see whether or not the desegregation of southern schools in the mid to late 1960s had long-run benefits for the students who were affected. ${ }^{24}$

Braddock, Crain, and McPartland (1984) review a series of papers that suggest that desegregation had potentially far-ranging effects on students' attitudes and subsequent matches with colleges, neighborhoods, and employers. Crain and Strauss (1985) is notable in that it exploits randomization in a desegregation program in Hartford, Connecticut and follows up with students years after they had completed their schooling. The authors find that black men and women who attended desegregated schools were more likely to work in white-collar jobs than other blacks in their same cohort, and that the men in particular attained more education.

Boozer, Krueger, and Wolkon (1992) go further in advancing a causal link between integrated schooling and labor market achievement for a much broader sample of workers. Using the sample from the National Survey of Black Americans, they find a negative correlation between school segregation and subsequent educational attainment and weekly wages (at 10 percent level of significance, including controls for age, region of residence, and state in which the respondent grew up). A two-stage least squares approach that relies heavily on the post-1964 discontinuity in school segregation produces roughly similar results for education and income, but with larger standard errors.

Guryan (2004) uses census data to study black high school dropout rates in the 1970s and finds that desegregation was associated with a two to three percentage point decline in dropouts. The finding

\footnotetext{
${ }^{24}$ There is a larger literature on the racial composition of schools and black students' educational and labor market outcomes. While valuable for current policy debates, these studies typically study cohorts that came along years after the late 1960s sea change in the southern educational system. That is, they tend not to assess the impact of the event of southern school desegregation (which is our focus) but rather the more general phenomenon of peer effects. See Grogger (1996), Rivkin (2000), or Hanushek, Kain, and Rivkin (2002).
} 
holds up even with a long list of controls for family characteristics and location-specific trends. Interestingly, he also finds that "there does not seem to be any evidence that the length of exposure to integration has a compounding effect on dropout rates" (p. 21). That is, students who had been in desegregated schools for a longer period of time did not seem to benefit more than those with a relatively short period of exposure.

Reber (2004) studies changes in high school enrollment and graduation rates for blacks in Louisiana, where expenditures on black schools still lagged behind those of white schools just before desegregation. The results suggest that black student outcomes were especially responsive to changes in school funding associated with desegregation, more so than to changes in exposure to white students.

These studies cannot clearly identify the channel(s) through which desegregation affected outcomes, but three potential channels deserve careful consideration. First, even though easily measured school resources may have been near equal by the time of Brown, less tangible aspects of school quality might have been effectively equalized by desegregation. Second, it is possible that exposure to white peers had a positive effect on blacks' later outcomes, either through "socialization" and "assimilation" (see Braddock et al. 1984) or simply because the average levels of wealth and academic achievement happened to be higher among white peers. Third, it is possible that the event of desegregation itself (or the broader Civil Rights Movement) shifted some black students' perceptions about education and the future returns to educational attainment at a critical time in their academic careers.

\section{Econometric Approach}

A number of the studies mentioned above use individual-level data that reveal both the kind of school a particular person attended and the outcome of interest. This is valuable information, but the studies face serious econometric problems related to unobserved family and individual characteristics, sorting and selection into different kinds of school districts, and, often, the use of small samples. Boozer et al. (1992) and Guryan (2004) both try to deal with potential omitted variable and selection problems using instrumental variable approaches, whereas Crain and Strauss (1985) try to use randomization in 
Hartford's desegregation program.

We adopt a different approach by forgoing small data sets that link students and their school characteristics, and instead by making comparisons across large groups of people who were exposed to different schooling regimes (pre and post desegregation) solely because of when and where they were born. Our initial econometric approach compares the 1990 annual income of southern-born blacks who finished their secondary schooling just before desegregation with those who would have finished their schooling just after (or during the process of) desegregation. Non-southern-born blacks are used to control for cohort-specific factors that influence earnings (e.g., age), and state-of-residence fixed effects control for place-specific factors. Essentially, we are comparing age-earnings profiles for southern and non-southern born black men, after controlling for their place of residence.

Initially, our "southern-born" designation will apply specifically to the census-defined South. Therefore, both Kansas and Missouri natives are grouped with "non-southern-born" men despite the maintenance of segregated schools in these states prior to Brown. In the context of this investigation, this grouping might be preferred because desegregation occurred early in both states compared to the Deep South. But in any case, we also present results that exclude Border-State-born blacks to check the sensitivity of the results.

The identifying assumption is that there were no shocks that were correlated with the timing of southern desegregation and that had differential effects on income in 1990 across the regional birth-cohort groups. In this period's context, the assumption is difficult to defend completely (as we discuss below), but the design should mitigate several potential biases: cohort invariant region-of-birth effects are netted out; cohort invariant state-of-residence effects are netted out; and region-of-birth invariant cohort effects are netted out. Adding interaction terms for southern birth and state of residence to the base specification (Table 3A, column 1) has little effect on the coefficients of interest.

We use the 1990 IPUMS sample to examine the incomes of black men born from 1941 to 1960. Recall that desegregation began in earnest after the 1948 birth cohort. We grouped the men into five year-of-birth cohorts: 1941-44, 1945-48, 1949-52, 1953-56, 1957-60. We assigned men a "southern 
birth" dummy equal to 1 if they were born in the census South, and we interacted the cohort dummies and the southern-birth dummy.

The basic regression equation is

$$
\mathrm{Y}_{\mathrm{icsb}}=\alpha+\theta_{\mathrm{c}}+\gamma_{\mathrm{s}}+\delta_{\mathrm{b}}+\lambda_{\mathrm{cb}}+\mathrm{e}_{\mathrm{icsb}}
$$

where $\mathrm{Y}$ is $\log$ annual income, $\gamma$ is a vector of state-of-residence dummies, $\theta$ is a vector of birth-cohort dummies, $\delta$ is a dummy for southern birth, and $\lambda$ is a series of cohort-by-birth region effects. The pattern of coefficients on the interaction terms $(\lambda)$ is of particular interest since it tracks the differences (relative to the omitted cohort) in the intra-cohort wage gap for southern-born relative to northern-born workers (controlling for state of residence in 1990). If desegregation was associated with a sudden improvement in school quality, peer effects, or black students' perceptions of educational opportunity, then we would expect to see a pattern consistent with such improvements in the coefficients on $\lambda$. An alternative specification, discussed later, replaces the cohort-by-birth-region dummy variables with measures of the proportion of each cohort's students (by sub-region of birth) who attended all black high schools.

\section{Results and Problems of Interpretation}

Table 3A reports the regression results. Column 1 includes all black men in the relevant age range who reported positive income. ${ }^{25}$ Column 2 adds controls for educational attainment (a vector of dummies) and veteran status. Columns 3 and 4 are similar to 1 and 2 respectively, but they exclude blacks who were born in Border States because the pattern of desegregation in Border States was more gradual than in the Deep South. ${ }^{26}$ This permits a sharper contrast in the comparison groups, one that is more in line with the dramatic change depicted in Figure 1.

It is clear that in 1990 the intra-cohort log earnings gap between southern-born and non-southernborn men is smaller in the post-desegregation cohorts than in the pre-desegregation cohorts. The gap

\footnotetext{
${ }^{25}$ Adding state-of-birth effects to this specification has little effect on the coefficients of interest.

${ }^{26}$ Our "Border State" group includes Delaware, Kansas, Kentucky, Maryland, Missouri, Oklahoma, West Virginia, and Washington DC.
} 
narrows by about $0.10 \log$ points in column 1 and by about half that much in column $2 .{ }^{27}$ The results in column 2 are not statistically precise, but the nontrivial positive coefficients on the post-desegregation southern-born cohorts suggests that desegregation influenced long-run labor market outcomes by raising both educational attainment and income conditional on attainment. The southern-born 1945-48 cohort performs only slightly better than the 1941-44 cohort relative to their northern-born peers, implying that there was not simply a strong upward trend for successive cohorts. At the $25^{\text {th }}$ and $50^{\text {th }}$ percentile, quantile regression coefficients on the interactions of southern-birth and cohort are similar to the OLS results in column 1, but they are about half as large at the 75th percentile (not shown).

Excluding blacks born in Border States (about 10 percent of the original sample) yields similar but somewhat stronger results in columns 3 and 4. The magnitude of the increase for the 1949-1952 birth cohort relative to later ones is a bit puzzling. The level of desegregation was declining rapidly when this group would have been in high school, but it was still high relative to that experienced by younger cohorts. This would be consistent with an effect from a discontinuous change in southern black students' perception of the value of education even before desegregation, perhaps associated with the passage of the Civil Rights Act of 1964 and Voting Rights Act of 1965.

In columns 5 and 6 of Table 3, we try to exploit the NSBA data more thoroughly. The NSBA is not a large sample, and so generating state-specific time series of segregation is generally infeasible. Instead, we have broken the country into five subregions of birth (Non-South, South Atlantic, Border, East South Central, and West South Central) and estimated the degree of segregation experienced by each birth cohort in each subregion (measured as the proportion of students in each cohort-by-subregion category that attended all black high schools). The "sub-region-by-cohort segregation" variable replaces the region-by-cohort dummy variables. In column 5, without controls for education attainment and veteran status, there is a strong correlation between segregated schooling and income in $1990 .^{28}$ The correlation is much weaker once educational attainment and veteran status enter the regressions (column

\footnotetext{
${ }^{27}$ If only veteran status is added to the regression (not educational attainment), the results are fairly similar to those in column 1, so we emphasize the educational attainment aspect.

${ }^{28}$ Adding state of birth dummy variables strengthens the coefficient on segregated schooling $(-0.096, \mathrm{t}-\mathrm{stat}=4.4)$.
} 
$6)$.

While these basic results are consistent with a positive effect from the dismantling of the segregated educational system in the South, the interpretation of the patterns is open to debate. For example, compulsory military service might have been more common in some birth cohorts than others, and it is possible that those born in one region were more likely to serve than those born elsewhere, and it is possible that service had a long-term effect on labor market outcomes. ${ }^{29}$ But we found that controlling for veteran status directly (without controls for educational attainment) had a small effect on the results.

A more difficult potential problem is that the post-desegregation birth cohorts might have timed their entry into the labor market especially well in that many began working just as the full force of the federal anti-discrimination effort was brought to bear on labor markets. This is possible, but it would require that the southern-born post-desegregation cohort benefited significantly more than the immediate pre-desegregation cohort relative to non-southern-born men in the same age cohorts (and conditional on their state of residence). Moreover, it would require that the post-desegregation cohort continued to enjoy those differential benefits as late as 1990 (26 years after the Civil Rights Act). ${ }^{30}$

Another competing interpretation would be that northern-born blacks in the later cohorts experienced unobserved adverse shocks to the cities they grew up in, and that these had long-lasting labor market consequences that are not absorbed by the place of residence dummies. For example, Collins and Margo (2004) find that severe riots in the late 1960s negatively affected blacks' income and employment. Omitting residents of the four most severe riot cities (Detroit, Los Angeles, Newark, and Washington DC) has little effect on the coefficients of interest in Table 3A, but the more general point regarding potential unobserved shocks to northern-born cohorts cannot be dismissed.

Table 3B's regression specifications are similar to those in Table 3A (specifically, Table 3A's

\footnotetext{
${ }^{29}$ See Angrist (1990) on Vietnam service and income later in life.

${ }^{30}$ Beaudry and DiNardo (1991) find that individuals' earnings (circa 1979 and 1983) are best described by a model in which workers are costlessly mobile and form implicit contracts with firms. A model in which people are immobile and form implicit contracts and a spot market model are also considered. The results suggest that current earnings are more sensitive to the best labor market conditions one experiences while with a particular employer than to the labor market conditions at the start of one's job or at the time of the survey. The connection between Beaudry and Dinardo's findings and this paper's results are not direct, but their results suggest that labor market conditions at the time of entry may be of limited importance in driving our results.
} 
columns 1, 3, and 5), but high-school completion is the dependent variable. ${ }^{31}$ Later cohorts of southernborn blacks clearly narrowed the high school graduation gap relative to non-southern-born blacks, by about nine percentage points by the 1957-60 birth cohort. This progression is somewhat smoother than the one observed for income in Table 3A, making it difficult to rule out a pre-existing trend.

It is possible that the results in Tables 3A and 3B merely reflect convergence by southern-born men (white and black) on those born elsewhere in the country. That is, perhaps the patterns we observe are manifestations of a secular process of inter-regional convergence that was independent of school desegregation. If so, we would expect to find similar patterns in the outcomes for white students' in the same birth cohorts. Table 4 reports regressions for white men that are similar in specification to those that reported for blacks in columns 1 and 2 of Table 3A and column 1 of Table 3B. There is evidence of an upward drift in southern-born whites' income relative to non-southern-born whites, but it is both more gradual and smaller than the pattern of change evident for blacks, and it nearly disappears when educational attainment and veteran status are added to the regression in column 2. Column 3 also suggests some convergence of southern-born and non-southern-born white men in high school graduation rates, but again, the pattern is more gradual and the gains are smaller for whites than for blacks.

If one believes that whites are a useful control group (that is, unaffected by desegregation but reflecting a secular inter-regional trend), then the difference between the black and white coefficients yields a difference-in-difference-in-difference (DDD) measure of desegregation's influence on blacks' average earnings and high school graduation rates. The income DDD is approximately 5 to $6 \log$ points (based on column 1 in Table 3A and Table 4), and the high school completion DDD is approximately 3 to 5 percentage points (based on column 1 in Table 3B and column 3 in Table 4).

In principle, this line of investigation could be extended, but there are several constraints, some due to limits in the available data and some due to limits in the approach itself. The most compelling extension would be to use more cross-place variation in the timing of desegregation to measure

\footnotetext{
${ }^{31}$ We use this variable because the 1990 census reports educational attainment by categories whereas previous censuses reported years of schooling. It also corresponds more closely to the investigations by Guryan (2004) and Reber (2004).
} 
desegregation effects. This consideration motivated the regressions in columns 5 and 6 of Tables $3 \mathrm{~A}$ and 3B. Unfortunately, the National Survey of Black Americans is not very large, and it gets stretched thin in pursuing this empirical strategy. Another extension would be to assemble a measure of exposure to desegregated schools. Perhaps students with a longer exposure to desegregated schools reaped more benefits than those who had only a few years (or less) exposure. This would run contrary to the pattern of results in Table 3A, and to Guryan's (2004) findings mentioned above, but it is certainly worth exploring.

\section{Conclusions}

The pieces of evidence that we have assembled in this paper's narrative are imperfect, and therefore the inferences based upon them are open to doubt and debate. Nonetheless, the basic results are highly suggestive and fairly robust. It appears that the diversion of resources from black schools prior to the Brown ruling had long-run effects on the labor market and educational outcomes of black workers, both directly and through intergenerational channels. From 1930 to 1960, southern administrators moved toward equalizing basic school resources in the hope of maintaining separate schools by finally living up to the promise of being "equal". We estimate that increasing the level of educational inputs for black students born in the 1920s and 1930s to match the inputs devoted to whites in the same state would have added a non-trivial sum to black men's average annual income in 1970. The school quality gap, and therefore the lost earnings, were larger for the 1920s birth cohort than for the 1930s birth cohort.

As school resources equalized, Civil Rights activists were already preparing to target the South's entire system of racial exclusion and discrimination, including a legal challenge to segregation in public schools. In 1942, the desegregation of schools was an immensely unpopular proposition to southern whites: only 2 percent thought that white and black students should go to school together (Greeley and Sheatsley 1971). Twelve years later, the Supreme Court signaled that the segregated system's days were numbered in its Brown v. Board decision. And ten years after that, the promise of desegregation started to become a reality.

Inter and intra cohort income patterns in 1990 suggest that school desegregation had an 
economically significant, positive effect on blacks' income and high school completion rates. The patterns are open to alternative interpretations, and they provide limited insight into the mechanisms through which desegregation might have had its effect, but our estimates add to a growing list of positiveleaning estimates of desegregation's effect, as in Boozer, Krueger, and Wolkon (1992), Guryan (2004), and Reber (2004). Given the historical and policy significance of this hypothesis, we believe that it deserves much more thorough scrutiny.

Although this paper focuses on the labor market implications of racial segregation in southern schools, it is certainly possible that the full effect of the Brown decision was much broader. While some legal scholars, most notably Gerald Rosenberg (1991), question Brown's ability to effectuate social change, many others believe Brown and the aftermath of the decision were deeply influential. Klarman (1994), for example, argues that the southern response to Brown, which elevated the power and visibility of staunch segregationists, provoked the subsequent, strong federal response and may also have facilitated public acceptance of desegregation. Likewise, Brown may have influenced the course of legal thought on matters of segregation, discrimination, and the potential range of legal remedies for such problems. ${ }^{32}$ At the very least, as suggested by Figure 2, the impact of Brown continues to resonate both in case law and legal doctrine years after its decision. Finally, models of collective action suggest that the likelihood that an individual will lend support to a popular movement is influenced by the probability of the movement's success (Chong 1991) - that is, the belief that one's support could make a difference and be rewarded may be an important determinant of participation. In this sense, Brown may have spurred the Civil Rights Movement and contributed to policy changes that stretched far beyond school segregation.

\footnotetext{
${ }^{32}$ We thank Stewart Schwab for providing insight on this point.
} 


\section{$\underline{\text { References }}$}

Anderson, James D. 1988. The Education of Blacks in the South, 1860-1935. Chapel Hill, NC: University of North Carolina Press.

Angrist, Joshua D. 1990. "Lifetime Earnings and the Vietnam Era Draft Lottery: Evidence from Social Security Administrative Records," 80 American Economic Review 313-336.

Beaudry, Paul, and John DiNardo. 1991. "The Effect of Implicit Contracts on the Movement of Wages Over the Business Cycle: Evidence from Micro Data," 99 Journal of Political Economy 665-688.

Blaustein, Albert P. and Clarence Clyde Ferguson, Jr. 1957. Desegregation and the Law: The Meaning and Effect of the School Desegregation Cases. New Brunswick, NJ: Rutgers University Press.

Bond, Horace Mann. 1934. The Education of the Negro in the American Social Order. New York, NY: Prentice-Hall.

Boozer, Michael A., Alan B. Krueger, Shari Wolkon. 1992. "Race and School Quality Since Brown v. Board of Education," Brookings Papers on Economic Activity, Microeconomics, 269-338.

Braddock, Jomills Henry II, Robert L. Crain, and James M. McPartland. 1984. "A Long-Term View of School Desegregation: Some Recent Students of Graduates as Adults," 66 Phi Delta Kappan 259264.

Caliver, Ambrose. 1933. Secondary Education for Negroes. United States Department of the Interior, National Survey of Secondary Education, Monograph 7. Washington, DC: Government Printing Office. [Reprinted: New York: Negro Universities Press, 1969.]

Card, David and Alan B. Krueger. 1991. "School Quality and Black-White Relative Earnings: A Direct Assessment.” NBER Working Paper 3713. Cambridge, MA: National Bureau of Economic Research.

Card, David and Alan B. Krueger. 1992. "School Quality and Black-White Relative Earnings: A Direct Assessment," 107 Quarterly Journal of Economics 151-200.

Card, David and Alan B. Krueger. 1996. "Labor Market Effects of School Quality: Theory and Evidence," in Gary Burtless, ed., Does Money Matter? The Link Between Schools, Student Achievement, and Adult Success. Washington, DC: Brookings Institution.

Chong, Dennis. 1991. Collective Action and the Civil Rights Movement. Chicago, IL: University of Chicago Press.

Clotfelter, Charles T. 2004. After Brown: The Rise and Retreat of School Desegregation. Princeton, NJ: Princeton University Press.

Coleman, James S. et al. 1966. Equality of Educational Opportunity. Washington, DC: Government Printing Office. [Reprint edition 1988, Salem, NH: Ayer Company.]

Collins, William J. and Robert A. Margo. 2003. "Historical Perspectives on Racial Differences in Schooling in the United States." NBER Working Paper 9770. Cambridge, MA: National Bureau of Economic Research. 
Collins, William J. and Robert A. Margo. 2004. "The Labor Market Effects of the 1960s Riots," in William G. Gale and Janet Rothenberg Pack, eds., Brookings-Wharton Papers on Urban Affairs 2004. Washinginton, DC: Brookings Institution.

Crain, Robert L. and Jack Strauss. 1985. "School Desegregation and Black Occupational Attainments: Results from a Long-term Experiment." Center for Social Organization of Schools. Baltimore, MD: Johns Hopkins University.

Donohue, John J. and James Heckman. 1991. "Continuous versus Episodic Change: The Impact of Civil Rights Policy on the Economic Status of Blacks" 24 Journal of Economic Literature 1603-1643.

Donohue, John J., James J. Heckman, and Petra E. Todd. 2002. "The Schooling of Southern Blacks: The Roles of Legal Activism and Private Philanthropy, 1910-1960," 117 Quarterly Journal of Economics 225-268.

Greeley, Andrew M. and Paul B. Sheatsley. 1971. “Attitudes toward Racial Integration,” 222 Scientific American (December) 13-19.

Grogger, Jeff. 1996. "Does School Quality Explain the Recent Black/White Wage Trend?" 14 Journal of Labor Economics 231-253.

Guryan, Jonathan. 2004. "Desegregation and Black Dropout Rates," 94 American Economic Review 919943.

Hanushek, Eric A., John F. Kain, and Steven G. Rivkin. 2002. "New Evidence about Brown v. Board of Education: The Complex Effects of School Racial Composition.” NBER Working Paper 8741. Cambridge, MA: National Bureau of Economic Research.

Heckman, James, Anne Layne-Ferrar, and Petra Todd. 1996. "Does Measured School Quality Really Matter?" in Gary Burtless, ed., Does Money Matter? The Link Between Schools, Student Achievement, and Adult Success. Washington, DC: Brookings Institution.

Jackson, James S. and Gerald Gurin. 1997. National Survey of Black Americans. Ann Arbor, MI: ICPSR 6668 .

Katz, Ellen D. 2003. "Reinforcing Representation: Congressional Power to Enforce the Fourteenth and Fifteenth Amendments in the Rehnquist and Wait Courts," 101 University of Michigan Law Review 2341-2408.

Klarman, Michael J. 1994. "Brown, Racial Change, and the Civil Rights Movement." 80 Virginia Law Review 7-150.

Kluger, Richard. 1975. Simple Justice: The History of Brown v. Board of Education and Black America's Struggle for Equality. New York, NY: Alfred A. Knopf.

Lassiter, Mathew D. and Andrew B. Lewis, eds. 1998. The Moderates' Dilemma: Massive Resistance to School Desegregation in Virginia. Charlottesville, VA: University Press of Virginia.

Margo, Robert A. 1986. Educational Achievement in Segregated School Systems: The Effects of 'Separate-but-Equal',' 76 American Economic Review 794-801.

Margo, Robert A. 1987. Accounting for Racial Differences in School Attendance in the American South, 
1900: The Role of Separate-but-Equal," 69 Review of Economics and Statistics 661-666.

Margo, Robert A. 1990. Race and Schooling in the South, 1880-1950: An Economic History. Chicago, IL: University of Chicago Press.

McPherson, James. 1964. The Struggle for Equality: Abolitionists and the Negro in the Civil Ward and Reconstruction. Princeton, NJ: Princeton University Press.

Murrell, Amy E. 1998. "The 'Impossible' Prince Edward Case: The Endurance of Resistance in a Southside County, 1959-65," in Matthew D. Lassiter and Andrew B. Lewis, eds., The Moderates' Dilemma: Massive Resistance to School Desegregation in Virginia. Charlottesville: University of Virginia Press.

Orazem, Peter. 1987. "Black-White Differences in School Investment and Human Capital Production in Segregated School Systems," 77 American Economic Review 714-723.

Orfield, Gary. 1969. The Reconstruction of Southern Education: The Schools and the 1964 Civil Rights Act. New York: Wiley-Interscience.

Reber, Sarah J. 2003. "Court Ordered Desegregation: Successes and Failures Integrating American Schools Since Brown.” Working paper.

Reber, Sarah J. 2004. "Desegregation and Educational Attainment for Blacks: Evidence from Louisiana" Working paper.

Rosenberg, Gerald N. 1991. The Hollow Hope: Can Courts Bring About Social Change? Chicago, IL: University of Chicago Press.

Ruggles, Steven, Matthew Sobek, Trent Alexander, Catherine A. Fitch, Ronald Goeken, Patricia Kelly Hall, Miriam King, and Chad Ronnander. 2004. Integrated Public Use Microdata Series: Version 3.0. Minneapolis, MN: Minnesota Population Center.

Rivkin, Steven G. 2000. "School Desegregation, Academic Attainment, and Earnings," 35 Journal of Human Resources 333-346.

Smith, A. Wade. 1981. "Tolerance of School Desegregation, 1954-77," 59 Social Forces 1256-1274.

Smith, James P. and Finis R. Welch. 1989. "Black Economic Progress After Myrdal," 27 Journal of Economic Literature 519-564.

Southern Education Reporting Service. 1965. Statistical Summary, State by State, of School SegregationDesegregation in the Southern and Border Area from 1954 to the Present. Nashville, TN.

Tushnet, Mark V. 1987. The NAACP's Legal Strategy Against Segregated Education, 1925-1950. Chapel Hill, NC: University of North Carolina Press.

U.S. Commission on Civil Rights. 1967. Racial Isolation in the Public Schools. Volumes 1 and 2. Washington, DC: Government Printing Office.

U.S. Commission on Civil Rights. 1977. Reviewing a Decade of School Desegregation, 1966-1975: Report of a National Survey of School Superintendents. Staff Report. Washington, DC. 
Vigdor, Jacob L. 2002. “The Pursuit of Opportunity: Explaining Selective Black Migration,” 51 Journal of Urban Economics 391-417.

Welch, Finis and Audrey Light. 1987. New Evidence on School Desegregation, U.S. Commission on Civil Rights, Clearinghouse Publication 92.

Wilkerson, Doxey A. 1939. Special Problems of Negro Education, The Advisory Committee on Education, Staff Study Number 12. Washington, DC: U.S. Government Printing Office. [Reprinted in 1970 by Negro University Press, Westport, CT.] 
Table 1: Southern School Characteristics, by Race, 1890-1960

\begin{tabular}{|c|c|c|c|c|c|c|c|c|c|}
\hline & $\begin{array}{l}\text { Margo, } \\
\text { Alabama, } \\
\text { Black }\end{array}$ & $\begin{array}{l}\text { Margo, } \\
\text { Alabama, } \\
\text { White }\end{array}$ & $\begin{array}{l}\text { Margo, } \\
\text { Alabama, } \\
\text { Gap }\end{array}$ & $\begin{array}{l}\text { CK, } \\
\text { South, } \\
\text { Black }\end{array}$ & $\begin{array}{l}\text { CK, } \\
\text { South, } \\
\text { White }\end{array}$ & $\begin{array}{l}\text { CK, } \\
\text { South, } \\
\text { Gap }\end{array}$ & $\begin{array}{l}\text { DHT, } \\
\text { Georgia, } \\
\text { Black }\end{array}$ & $\begin{array}{l}\text { DHT, } \\
\text { Georgia, } \\
\text { White }\end{array}$ & $\begin{array}{l}\text { DHT, } \\
\text { Georgia, } \\
\text { Gap }\end{array}$ \\
\hline \multicolumn{10}{|c|}{ Panel A: Days in School Term } \\
\hline 1890 & 75 & 70 & 5 & --- & --- & --- & --- & --- & --- \\
\hline $1910 / 11$ & 97 & 131 & 34 & --- & --- & --- & 119 & 134 & 15 \\
\hline 1915 & --- & --- & --- & 106 & 139 & 33 & --- & --- & --- \\
\hline 1920 & --- & --- & --- & 116 & 141 & 25 & 129 & 143 & 14 \\
\hline 1930 & --- & --- & --- & 132 & 163 & 31 & 131 & 153 & 22 \\
\hline $1935 / 38$ & 127 & 144 & 17 & 153 & 170 & 17 & 153 & 170 & 17 \\
\hline 1950 & 177 & 176 & -1 & 173 & 177 & 4 & 177 & 180 & 3 \\
\hline 1960 & --- & --- & --- & 178 & 177 & -1 & 180 & 180 & 0 \\
\hline
\end{tabular}

Panel B: Students per Teacher (note Margo columns are attendance based; others are enrollment based)

\begin{tabular}{|c|c|c|c|c|c|c|c|c|c|}
\hline 1890 & 33.3 & 26.3 & 7.0 & --- & --- & --- & --- & --- & --- \\
\hline $1910 / 11$ & 39.7 & 27.3 & 12.4 & --- & --- & --- & 60 & 40 & 20 \\
\hline 1915 & --- & --- & --- & 60.8 & 37.6 & 23.2 & --- & --- & --- \\
\hline 1920 & --- & --- & --- & 57.3 & 36.4 & 20.9 & 59 & 41 & 18 \\
\hline 1930 & --- & --- & --- & 43.9 & 32.0 & 11.9 & 48 & 35 & 13 \\
\hline $1935 / 38$ & 36.7 & 26.1 & 10.6 & 39.7 & 29.8 & 9.9 & 43 & 30 & 13 \\
\hline 1950 & 28.1 & 24.7 & 3.4 & 32.6 & 27.4 & 5.2 & 36 & 32 & 4 \\
\hline 1960 & --- & --- & --- & 29.4 & 26.2 & 3.2 & 31 & 29 & 2 \\
\hline
\end{tabular}

Notes: Margo's figures pertain to schools in Alabama. He reports figures for other states as well, but not a southern aggregate, and Alabama seems reasonably representative (at least of the Deep South). "CK" stands for Card and Krueger. The figures are taken from table 6 of their NBER Working Paper (3713); a comparable table is not available in the 1992 version of the paper (graphs are). States with segregated schools are included in their average (which is enrollment weighted). "DHT" stands for Donohue, Heckman, and Todd (2002) which reports specific figures for Georgia based on district-level data from the state's Board of Education. In general, the trends for Georgia appear to represent trends in the South well. Margo reports figures for 1910, whereas as DHT report figures for 1911. Margo reports figures for 1935, whereas DHT and CK report figures for 1938.

Sources: Figures are from Margo (1991), Card and Krueger (1991), Donohue, Heckman, and Todd (2002). 
Table 2A: Annual Income in 1970, Southern-Born Black Men Born 1920-1939

\begin{tabular}{|c|c|c|c|c|c|c|c|c|c|c|}
\hline & 1 & 2 & 3 & 4 & 5 & 6 & 7 & 8 & 9 & 10 \\
\hline Student/Teacher Ratio & $\begin{array}{l}-0.00808 \\
(3.45)\end{array}$ & $\begin{array}{l}-0.00985 \\
(3.24)\end{array}$ & $\begin{array}{l}-0.0107 \\
(3.39)\end{array}$ & $\begin{array}{l}-0.00520 \\
(1.14)\end{array}$ & $\begin{array}{l}-0.00800 \\
(1.99)\end{array}$ & ----- & ----- & ----- & ----- & ----- \\
\hline Length of School Term & ----- & ----- & ----- & ----- & ----- & $\begin{array}{l}0.00238 \\
(3.33)\end{array}$ & $\begin{array}{l}0.00375 \\
(4.90)\end{array}$ & $\begin{array}{l}0.00357 \\
(4.35)\end{array}$ & $\begin{array}{l}0.00252 \\
(2.36)\end{array}$ & $\begin{array}{l}0.00251 \\
(2.48)\end{array}$ \\
\hline 1930s Birth Cohort Dummy & $\begin{array}{l}0.0274 \\
(0.96)\end{array}$ & $\begin{array}{l}0.0168 \\
(0.50)\end{array}$ & $\begin{array}{l}0.00885 \\
(0.27)\end{array}$ & $\begin{array}{l}0.0192 \\
(0.61)\end{array}$ & $\begin{array}{l}-0.00113 \\
(0.04)\end{array}$ & $\begin{array}{l}0.0331 \\
(1.13)\end{array}$ & $\begin{array}{l}0.00145 \\
(0.05)\end{array}$ & $\begin{array}{l}0.00285 \\
(0.10)\end{array}$ & $\begin{array}{l}-0.00103 \\
(0.04)\end{array}$ & $\begin{array}{l}-0.00559 \\
(0.23)\end{array}$ \\
\hline Parents' Education & ----- & ----- & ----- & $\begin{array}{l}0.0446 \\
(1.79)\end{array}$ & $\begin{array}{l}0.0413 \\
(1.92)\end{array}$ & ----- & ----- & ----- & $\begin{array}{l}0.0398 \\
(1.82)\end{array}$ & $\begin{array}{l}0.0449 \\
(2.23)\end{array}$ \\
\hline $\begin{array}{l}\text { Sub-Region of Residence } \\
\text { Fixed Effects }\end{array}$ & No & Yes & Yes & Yes & Yes & No & Yes & Yes & Yes & Yes \\
\hline $\begin{array}{l}\text { Sub-Region of Birth Fixed } \\
\text { Effects }\end{array}$ & No & No & Yes & Yes & Yes & No & No & Yes & Yes & Yes \\
\hline $\begin{array}{l}\text { Sub-Region Birth } \times \\
\text { Residence Fixed Effects }\end{array}$ & No & No & No & No & Yes & No & No & No & No & Yes \\
\hline $\mathrm{N}$ & 14254 & 14254 & 14254 & 14254 & 14254 & 13992 & 13992 & 13992 & 13992 & 13992 \\
\hline
\end{tabular}

Notes: t-statistics are in parentheses; standard errors are clustered by state of birth and cohort. "Parents' Education" is a state-by-cohort specific measure of educational attainment based on the 1940 census. To assign values for the 1920-29 birth cohort, we observed years of education for people of age $35-55$ in 1940 in each southern state (who would have been 20-40 in 1925). For the 1930-39 birth cohort, we observed education for people of age $25-45$ in 1940 (who would have been 20-40 in 1935). Nine region of residence and four regions of birth are included as dummies where designated. The southern birth regions are Border, South Atlantic, East South Central, and West South Central. "Border" is not an official census designation but rather one we imposed on the data.

Sources: Individual data for 1970 and 1940 are from the IPUMS (Ruggles et al. 2004). School characteristics are from Card and Krueger (1992, pp. 197-198). 
Table 2B: Years of Schooling in 1970, Southern-Born Black Men Born 1920-1939

\begin{tabular}{|c|c|c|c|c|c|c|c|c|c|c|}
\hline & 1 & 2 & 3 & 4 & 5 & 6 & 7 & 8 & 9 & 10 \\
\hline Student/Teacher Ratio & $\begin{array}{l}-0.124 \\
(9.08)\end{array}$ & $\begin{array}{l}-0.135 \\
(12.24)\end{array}$ & $\begin{array}{l}-0.136 \\
(9.85)\end{array}$ & $\begin{array}{l}-0.0935 \\
(5.59)\end{array}$ & $\begin{array}{l}-0.103 \\
(6.37)\end{array}$ & $\begin{array}{ll}---- \\
\end{array}$ & ---- & ---- & ----- & $\begin{array}{ll}---- \\
-1\end{array}$ \\
\hline Length of School Term & ----- & ----- & ----- & ----- & ----- & $\begin{array}{l}0.0267 \\
(6.34)\end{array}$ & $\begin{array}{l}0.0366 \\
(8.48)\end{array}$ & $\begin{array}{l}0.0327 \\
(6.16)\end{array}$ & $\begin{array}{l}0.0199 \\
(4.33)\end{array}$ & $\begin{array}{l}0.0196 \\
(4.00)\end{array}$ \\
\hline 1930s Birth Cohort Dummy & $\begin{array}{l}0.439 \\
(2.19)\end{array}$ & $\begin{array}{l}0.359 \\
(2.48)\end{array}$ & $\begin{array}{l}0.345 \\
(2.29)\end{array}$ & $\begin{array}{l}0.424 \\
(3.62)\end{array}$ & $\begin{array}{l}0.346 \\
(2.89)\end{array}$ & $\begin{array}{l}0.808 \\
(3.40)\end{array}$ & $\begin{array}{l}0.571 \\
(3.07)\end{array}$ & $\begin{array}{l}0.638 \\
(3.71)\end{array}$ & $\begin{array}{l}0.591 \\
(4.69)\end{array}$ & $\begin{array}{l}0.574 \\
(4.60)\end{array}$ \\
\hline Parents' Education & ----- & ----- & ----- & $\begin{array}{l}0.343 \\
(4.45)\end{array}$ & $\begin{array}{l}0.342 \\
(4.90)\end{array}$ & ----- & ----- & ----- & $\begin{array}{l}0.485 \\
(7.16)\end{array}$ & $\begin{array}{l}0.515 \\
(7.82)\end{array}$ \\
\hline $\begin{array}{l}\text { Sub-Region of Residence } \\
\text { Fixed Effects }\end{array}$ & No & Yes & Yes & Yes & Yes & No & Yes & Yes & Yes & Yes \\
\hline $\begin{array}{l}\text { Sub-Region of Birth Fixed } \\
\text { Effects }\end{array}$ & No & No & Yes & Yes & Yes & No & No & Yes & Yes & Yes \\
\hline $\begin{array}{l}\text { Sub-Region Birth } \times \\
\text { Residence Fixed Effects }\end{array}$ & No & No & No & No & Yes & No & No & No & No & Yes \\
\hline $\mathrm{N}$ & 14254 & 14254 & 14254 & 14254 & 14254 & 13992 & 13992 & 13992 & 13992 & 13992 \\
\hline
\end{tabular}

Notes: Sample is restricted to include the same men as in Table 2A. t-statistics are in parentheses; standard errors are clustered by state of birth and cohort.

"Parents' Education" is a state-by-cohort specific measure of educational attainment based on the 1940 census. To assign values for the $1920-29$ birth cohort, we observed years of education for people of age 35-55 in 1940 in each southern state (who would have been 20-40 in 1925). For the 1930-39 birth cohort, we observed education for people of age 25-45 in 1940 (who would have been 20-40 in 1935). Nine region of residence and four regions of birth are included as dummies where designated. The southern birth regions are Border, South Atlantic, East South Central, and West South Central. "Border" is not an official census designation but rather one we imposed on the data.

Sources: See table 2A. 
Table 3A: Log Income in 1990,

by Region and Cohort of Birth, Native-Born Black Men

\begin{tabular}{|c|c|c|c|c|c|c|}
\hline & 1 & 2 & 3 & 4 & 5 & 6 \\
\hline Cohort 1945-48 & $\begin{array}{l}-0.0460 \\
(1.49)\end{array}$ & $\begin{array}{l}-0.1031 \\
(3.74)\end{array}$ & $\begin{array}{l}-0.0505 \\
(1.69)\end{array}$ & $\begin{array}{l}-0.1051 \\
(3.95)\end{array}$ & $\begin{array}{l}-0.0291 \\
(1.65)\end{array}$ & $\begin{array}{l}-0.0872 \\
(5.14)\end{array}$ \\
\hline Cohort 1949-52 & $\begin{array}{l}-0.1737 \\
(6.01)\end{array}$ & $\begin{array}{l}-0.2424 \\
(9.91)\end{array}$ & $\begin{array}{l}-0.1777 \\
(6.34)\end{array}$ & $\begin{array}{l}-0.2452 \\
(10.50)\end{array}$ & $\begin{array}{l}-0.1208 \\
(5.84)\end{array}$ & $\begin{array}{l}-0.2020 \\
(10.89)\end{array}$ \\
\hline Cohort 1953-56 & $\begin{array}{l}-0.2974 \\
(11.89)\end{array}$ & $\begin{array}{l}-0.3425 \\
(14.91)\end{array}$ & $\begin{array}{l}-0.3007 \\
(12.79)\end{array}$ & $\begin{array}{l}-0.3448 \\
(15.74)\end{array}$ & $\begin{array}{l}-0.2693 \\
(11.09)\end{array}$ & $\begin{array}{l}-0.3175 \\
(14.88)\end{array}$ \\
\hline Cohort $1957-60$ & $\begin{array}{l}-0.4282 \\
(19.02)\end{array}$ & $\begin{array}{l}-0.4446 \\
(21.52)\end{array}$ & $\begin{array}{l}-0.4395 \\
(21.76)\end{array}$ & $\begin{array}{l}-0.4559 \\
(24.96)\end{array}$ & $\begin{array}{l}-0.3963 \\
(17.82)\end{array}$ & $\begin{array}{l}-0.4285 \\
(21.93)\end{array}$ \\
\hline Southern Born & $\begin{array}{l}-0.0559 \\
(2.17)\end{array}$ & $\begin{array}{l}0.0705 \\
(2.96)\end{array}$ & $\begin{array}{l}-0.0653 \\
(2.84)\end{array}$ & $\begin{array}{l}0.0680 \\
(3.11)\end{array}$ & $\begin{array}{l}0.0459 \\
(2.52)\end{array}$ & $\begin{array}{l}0.1104 \\
(7.84)\end{array}$ \\
\hline Southern Born $\times$ Cohort 1945-48 & $\begin{array}{l}0.0269 \\
(0.72)\end{array}$ & $\begin{array}{l}0.0210 \\
(0.62)\end{array}$ & $\begin{array}{l}0.0332 \\
(0.92)\end{array}$ & $\begin{array}{l}0.0254 \\
(0.76)\end{array}$ & ----- & ----- \\
\hline Southern Born $\times$ Cohort 1949-52 & $\begin{array}{l}0.1020 \\
(2.78)\end{array}$ & $\begin{array}{l}0.0605 \\
(1.89)\end{array}$ & $\begin{array}{l}0.1141 \\
(3.24)\end{array}$ & $\begin{array}{l}0.0716 \\
(2.31)\end{array}$ & ----- & ----- \\
\hline Southern Born $\times$ Cohort 1953-56 & $\begin{array}{l}0.1018 \\
(3.00)\end{array}$ & $\begin{array}{l}0.0459 \\
(1.51)\end{array}$ & $\begin{array}{l}0.1162 \\
(3.75)\end{array}$ & $\begin{array}{l}0.0560 \\
(1.98)\end{array}$ & ----- & ----- \\
\hline Southern Born $\times$ Cohort 1957-60 & $\begin{array}{l}0.1101 \\
(3.29)\end{array}$ & $\begin{array}{l}0.0319 \\
(1.11)\end{array}$ & $\begin{array}{l}0.1348 \\
(4.28)\end{array}$ & $\begin{array}{l}0.0508 \\
(1.86)\end{array}$ & ----- & ----- \\
\hline Subregion-by-Cohort Segregation Measure & ----- & ----- & ----- & ----- & $\begin{array}{l}-0.0945 \\
(2.99)\end{array}$ & $\begin{array}{l}-0.0186 \\
(0.70)\end{array}$ \\
\hline Constant & $\begin{array}{l}9.603 \\
(270.2)\end{array}$ & $\begin{array}{l}8.852 \\
(298.4)\end{array}$ & $\begin{array}{l}9.603 \\
(285.9)\end{array}$ & $\begin{array}{l}8.861 \\
(315.8)\end{array}$ & $\begin{array}{l}9.595 \\
(236.0)\end{array}$ & $\begin{array}{l}8.835 \\
(285.9)\end{array}$ \\
\hline Control for education and vet status & No & Yes & No & Yes & No & Yes \\
\hline Exclude those born in border states & No & No & Yes & Yes & No & No \\
\hline Fixed effects, state of residence & Yes & Yes & Yes & Yes & Yes & Yes \\
\hline $\mathrm{N}$ & 130,130 & 130,130 & 117,310 & 117,310 & 130,130 & 130,130 \\
\hline
\end{tabular}

Notes: t-statistics are in parentheses; standard errors are clustered by state of birth and cohort. The omitted birth cohort dummy is for the 1941-1944 group, and the omitted birth region is ANon-South@ Other birth cohorts are grouped as: 1945-48, 1949-52, 1953-56, and 1957-60. Roughly, the 1941-44 and 1945-48 cohorts would have finished their formal schooling before public school desegregation started in earnest in the Deep South (after 1964). The "Subregion-by-Cohort Segregation Measure" is calculated using the NSBA. It is the proportion of students in each age cohort who attended all black high schools, by sub-region of where respondents "mostly grew up" (NonSouth, South Atlantic, Border, East South Central, and West South Central).

Source: Individual data from 19905 percent sample, IPUMS (Ruggles et al. 2004). The measure of the prevalence of segregated schooling is calculated using the National Survey of Black Americans (Jackson and Gurin 1997). 
Table 3B: Likelihood of High School Completion in 1990, by Region and Cohort of Birth, Native-Born Black Men

\begin{tabular}{|c|c|c|c|}
\hline & 1 & 2 & 3 \\
\hline Cohort 1945-48 & $\begin{array}{l}0.0450 \\
(3.46)\end{array}$ & $\begin{array}{l}0.0476 \\
(3.44)\end{array}$ & $\begin{array}{l}0.0607 \\
(5.04)\end{array}$ \\
\hline Cohort 1949-52 & $\begin{array}{l}0.0671 \\
(4.60)\end{array}$ & $\begin{array}{l}0.0666 \\
(4.18)\end{array}$ & $\begin{array}{l}0.0924 \\
(8.48)\end{array}$ \\
\hline Cohort 1953-56 & $\begin{array}{l}0.0567 \\
(4.46)\end{array}$ & $\begin{array}{l}0.0566 \\
(4.06)\end{array}$ & $\begin{array}{l}0.0733 \\
(6.85)\end{array}$ \\
\hline Cohort 1957-60 & $\begin{array}{l}0.0461 \\
(3.41)\end{array}$ & $\begin{array}{l}0.0461 \\
(3.14)\end{array}$ & $\begin{array}{l}0.0688 \\
(6.14)\end{array}$ \\
\hline Southern Born & $\begin{array}{l}-0.123 \\
(7.09)\end{array}$ & $\begin{array}{l}-0.129 \\
(6.85)\end{array}$ & $\begin{array}{l}-0.0473 \\
(6.50)\end{array}$ \\
\hline Southern Born $\times$ Cohort 1945-48 & $\begin{array}{l}0.0252 \\
(1.24)\end{array}$ & $\begin{array}{l}0.0227 \\
(1.06)\end{array}$ & ----- \\
\hline Southern Born $\times$ Cohort 1949-52 & $\begin{array}{l}0.0586 \\
(2.89)\end{array}$ & $\begin{array}{l}0.0599 \\
(2.75)\end{array}$ & ----- \\
\hline Southern Born $\times$ Cohort 1953-56 & $\begin{array}{l}0.0753 \\
(3.98)\end{array}$ & $\begin{array}{l}0.0784 \\
(3.84)\end{array}$ & ----- \\
\hline Southern Born $\times$ Cohort 1957-60 & $\begin{array}{l}0.0868 \\
(4.43)\end{array}$ & $\begin{array}{l}0.0924 \\
(4.41)\end{array}$ & ----- \\
\hline Subregion-by-Cohort Segregation Measure & ----- & ----- & $\begin{array}{l}-0.0775 \\
(5.18)\end{array}$ \\
\hline Constant & $\begin{array}{l}0.705 \\
(41.32)\end{array}$ & $\begin{array}{l}0.707 \\
(39.41)\end{array}$ & $\begin{array}{l}0.704 \\
(41.80)\end{array}$ \\
\hline Exclude those born in border states & No & Yes & No \\
\hline Fixed effects, state of residence & Yes & Yes & Yes \\
\hline $\mathrm{N}$ & 130,130 & 117,310 & 130,130 \\
\hline
\end{tabular}

Notes: Estimates are from linear probability models. t-statistics are in parentheses; standard errors are clustered by state of birth and cohort. The omitted birth cohort dummy is for the 1941-1944 group, and the omitted birth region is ANon-South@ Other birth cohorts are grouped as: 1945-48, 1949-52, 1953-56, and 1957-60. Roughly, the 1941-44 and 1945-48 cohorts would have finished their formal schooling before public school desegregation started in earnest in the Deep South (after 1964). The "Subregion-by-Cohort Segregation Measure" is calculated using the NSBA. It is the proportion of students in each age cohort who attended all black high schools, by sub-region of where respondents "mostly grew up" (Non-South, South Atlantic, Border, East South Central, and West South Central). These are not official census designations of sub-regions.

Source: Individual data from 19905 percent sample, IPUMS (Ruggles et al. 2004). The measure of the prevalence of segregated schooling is calculated using the National Survey of Black Americans (Jackson and Gurin 1997). 
Table 4: Log Income and Likelihood of High School Completion in 1990, by Region and Cohort of Birth, Native-Born White Men

\begin{tabular}{|c|c|c|c|}
\hline & 1: Income & 2: Income & 3: High School \\
\hline Cohort 1945-48 & $\begin{array}{l}-0.0260 \\
(1.65)\end{array}$ & $\begin{array}{l}-0.0714 \\
(7.46)\end{array}$ & $\begin{array}{l}0.0333 \\
(8.36)\end{array}$ \\
\hline Cohort 1949-52 & $\begin{array}{l}-0.1102 \\
(7.01)\end{array}$ & $\begin{array}{l}-0.1638 \\
(17.93)\end{array}$ & $\begin{array}{l}0.0454 \\
(11.33)\end{array}$ \\
\hline Cohort 1953-56 & $\begin{array}{l}-0.2057 \\
(13.64)\end{array}$ & $\begin{array}{l}-0.2290 \\
(26.65)\end{array}$ & $\begin{array}{l}0.0366 \\
(8.25)\end{array}$ \\
\hline Cohort 1957-60 & $\begin{array}{l}-0.3355 \\
(20.70)\end{array}$ & $\begin{array}{l}-0.3320 \\
(35.41)\end{array}$ & $\begin{array}{l}0.0182 \\
(3.17)\end{array}$ \\
\hline Southern Born & $\begin{array}{l}-0.1566 \\
(8.73)\end{array}$ & $\begin{array}{l}-0.0396 \\
(3.92)\end{array}$ & $\begin{array}{l}-0.0985 \\
(10.22)\end{array}$ \\
\hline Southern Born $\times$ Cohort 1945-48 & $\begin{array}{l}0.0241 \\
(1.07)\end{array}$ & $\begin{array}{l}0.0135 \\
(1.02)\end{array}$ & $\begin{array}{l}0.0147 \\
(1.34)\end{array}$ \\
\hline Southern Born $\times$ Cohort 1949-52 & $\begin{array}{l}0.0410 \\
(1.75)\end{array}$ & $\begin{array}{l}0.0134 \\
(0.92)\end{array}$ & $\begin{array}{l}0.0320 \\
(3.11)\end{array}$ \\
\hline Southern Born $\times$ Cohort 1953-56 & $\begin{array}{l}0.0536 \\
(2.49)\end{array}$ & $\begin{array}{l}0.0111 \\
(0.91)\end{array}$ & $\begin{array}{l}0.0327 \\
(3.22)\end{array}$ \\
\hline Southern Born $\times$ Cohort 1957-60 & $\begin{array}{l}0.0484 \\
(2.05)\end{array}$ & $\begin{array}{l}-0.0012 \\
(0.08)\end{array}$ & $\begin{array}{l}0.0398 \\
(3.71)\end{array}$ \\
\hline Constant & $\begin{array}{l}10.31 \\
(457.6)\end{array}$ & $\begin{array}{l}9.363 \\
(661.68)\end{array}$ & $\begin{array}{l}0.854 \\
(100.4)\end{array}$ \\
\hline Control for education and vet status & No & Yes & ----- \\
\hline Exclude those born in border states & No & No & No \\
\hline Fixed effects, state of residence & Yes & Yes & Yes \\
\hline $\mathrm{N}$ & $1,396,319$ & $1,396,319$ & $1,396,319$ \\
\hline
\end{tabular}

Notes: t-statistics are in parentheses; standard errors are clustered by state of birth and cohort. The omitted birth cohort dummy is for the 1941-1944 group, and the omitted birth region is ANon-South@ Other birth cohorts are grouped as: 1945-48, 1949-52, 1953-56, and 1957-60.

Source: 19905 percent sample, IPUMS (Ruggles et al. 2004). 
Figure 1: Proportion of Black Respondents Attending All Black High Schools, by Birth Cohort and Birth Region
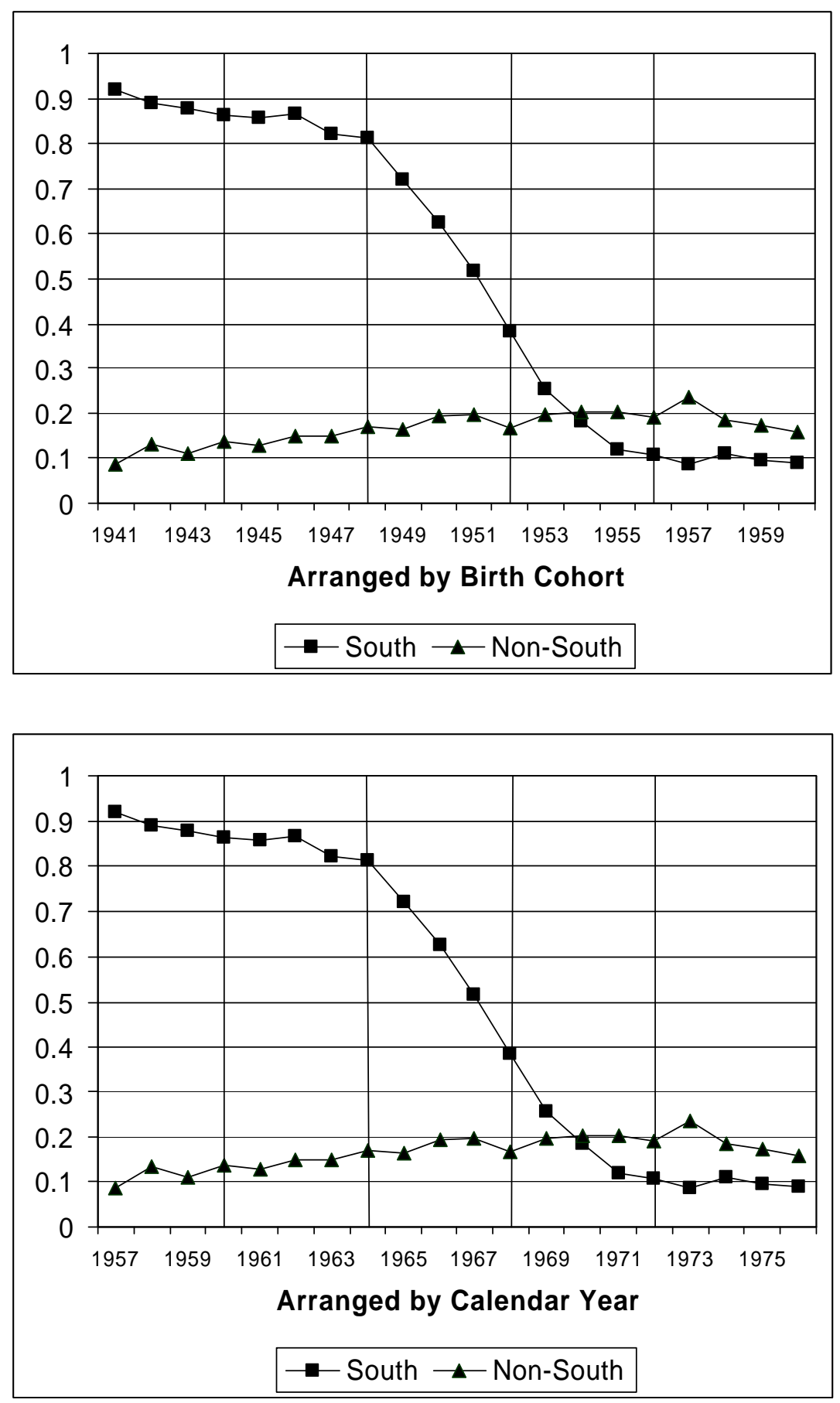

Notes: The horizontal axis of the top graph plots the birth cohort. The horizontal axis of the bottom graph plots an estimate by calendar year (birth cohort plus 16). Vertical lines denote the birth-cohort groupings. "South" refers to the Deep South. Respondents who reported "growing up mostly" in border states are excluded from the sample. Moving averages are used to smooth the plots which is particularly useful for the non-southern-born group (which is relatively small). For southern-born blacks, the timing and magnitude of change is not affected by the smoothing. Source: Calculated using data from the National Survey of Black Americans (Jackson and Gurin 1997). 
Figure 2: Citing References to Brown v. Board of Education, by Year

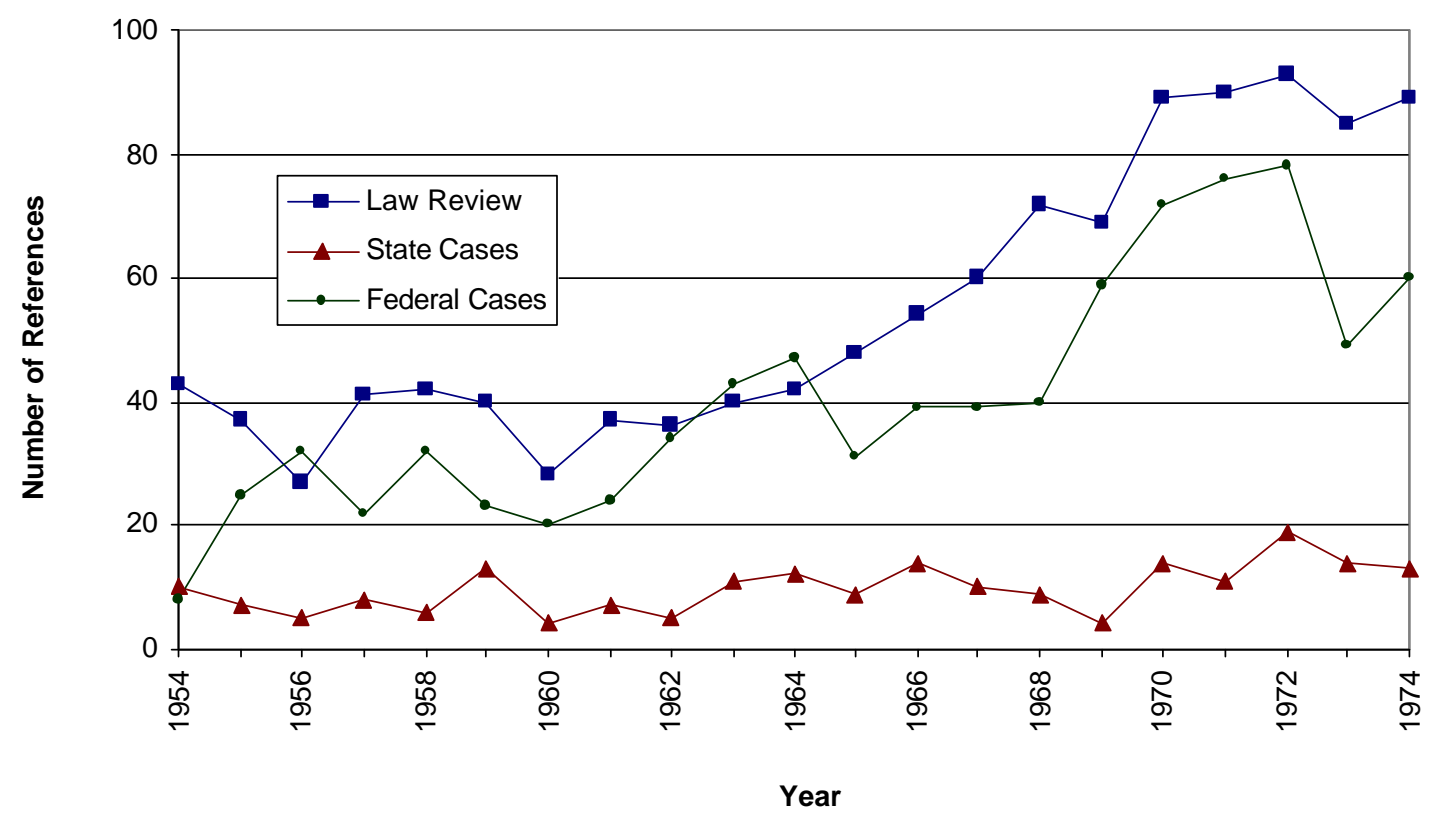

